するととが示されている。

\subsection{1 : 539.413.096}

〔307〕耐熱性プラスチックス皘嚅品の高温強度

[B. M. Axilrod and M. A. Sherman, J. Research of the National Bureau of Standards, $1950-7$, Vol. 45, p. 65 84, 困 10, 表 7】齐 7 ラス繊維の積層板

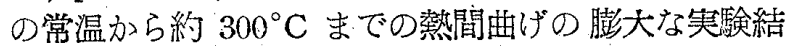
集である。積尿用の樹脂は不飽和ポリエステル，アク リル，けい素，石炭酸衫よびメラミン系のものであ る. 実験条件は（1） $150 \sim 250^{\circ} \mathrm{C}$ 亿 200 時間保つた後 $25^{\circ} \mathrm{C}$, 相刘湿度 $50 \%$ で実験，（2） $150 \sim 375^{\circ} \mathrm{C}$ 亿 $0^{\circ} 5$ 時間保つた後同一高温度で实験，（3） $150 \sim 325^{\circ} \mathrm{C}$ 亿 200時間保つた後同一高温展で実験，(4) conditioning なしで $25^{\circ} \mathrm{C}$ 相対湿度 $50 \%$ で害験の 4 種類である.こ れらの結果では， $250^{\circ} \mathrm{C}$ あるいそれ以上の高温曲げ 強度はけい素樹脂積層品が最もすぐれている，石炭酸

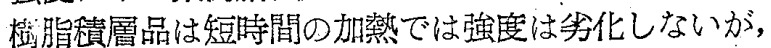
長時間 (200 時間)ではかなり弱化する.メラミン樹脂 は200 $250^{\circ} \mathrm{C}$ に長時間加熱した時の曲げ強度の低下 は石炭酸樹脂の場合よりも小さい. ポリエステル樹脂

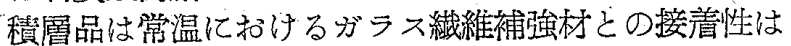
よいが， $250^{\circ} \mathrm{C}$ 附近では相当強度は低下゙する。いずれ
の樹脂の場合も弾性係数の高温における低下゙は曲げ破 罣係数の低下はど顕著ではない。【伊藤 勝辰〕

\subsubsection{7 : 67.8-419}

[308]ガラス織維の表面処理の影警評価 [G. A. Clark, Modern Plastics, 1952-10, p. 142 144, $218 ， 219$ ，図 2, 表 7〕低圧積層用補強杼としてポ リエステル樹脂と組合わされるガラス瀻維の表面処理 は程绸品の強度特に湿式強度の改善に重要な問題であ

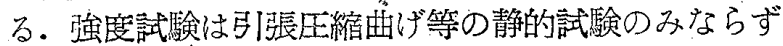
瘦れ試験までも行われている。湿式強度には 50〜100 \%相洸湿度抽よび浸水等の長時間露出の外に，2３㭙

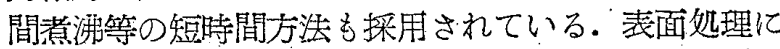
よる湿式強度の低下は従来の114 Finish は約 30\% 亿 も文んで大きいが，Bjorksten Finish は約 5\%で強 度低下もきわめて少くかつ強度自身の值も他の表面処 理厅浩に比べて最も大きい，また機械的性質と並んで 電気的性犋の測定も行われている。すなわち誘䉓率打 よび誘電体力率は各種の表面処理で大して変化は認め られないが， 24 時間浸水後 $73^{\circ} \mathrm{F}$ でのそれらの值は， 表面処理 114 Finish の方がやや劣っている.

[伊滕 勝离]

\title{
3. 測定機および測定法
}

\section{$532.574-3$}

[309] 3 次元流れの測定装置 [R. L. Hanstad, Proc. 2 nd Midwest, Conf. Fluid Mech., 1952, p. 521 〜 529, 図 11, 東京大学理工研河田研究室所在了軸 流送風機，タービン，燃烍窒内などの複雑な 3 负元的 流れの流速, 動圧, 重直扣よび水平方向の流れの偏府 を簡単な一つの装置で測るととを研究している。試作 した装置は，宜径 $1 / 4$ in の球に支持棒のついたもの で，球の表面には苜堡 0.008 in の小穴が三つあけて

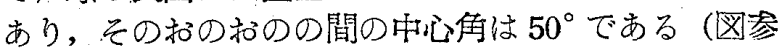
照)。球は支持棒の軸のま わりに回転可能である．水 平面内の流れの偏角は穴 $M$ に礼ける压力が最大になる 触度方決定し，更にての 点加穴穴 $T$, 穴 $B$ に打ける 压力差が 0 になる宗での回 転隹を測り，簡単な三角㴻

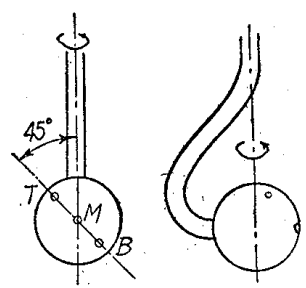
によって垂直面内の流れの偏角を求めることがでさ る. また穴 $M$ が流れと $45^{\circ}$ をなすような位置に来た 時，乙の点の压力が流れの静圧と等しくなることを利 用して静压, 動压したがって流速を湘定するてとがで き。

[河村 䉓馬]

\section{$536.532: 533.6$}

[310]高方ス温度測定用 N.A.C.A. 吾速オリフィ ス温度測定管 [P. L. Blackshear, A.S.M.E., Trans., 1953-1, Vol. 75, No. 1, p. 51 58, 図 16] 困の ごとき“温度測定管”を流れの中に挿入し，二つの直 列のオリフィスを通るガスの速度わ゙胥速となるように

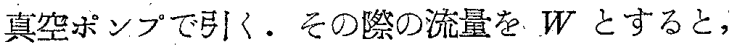

$$
W=\frac{P_{1} A_{1}}{f\left(\gamma_{1}\right) \sqrt{g R T_{1}}}=\frac{P_{2} A_{2}}{f\left(\gamma_{2}\right) \sqrt{g R T_{2}}} \cdots \cdots
$$

ゆえに

$$
T_{1}=\left[\frac{P_{1} A_{1} f\left(\gamma_{2}\right)}{P_{2} A_{2} f\left(\gamma_{1}\right)}\right] T_{2}
$$

ただし $P=$ 全压， $T$ =岐点温度， $A=$ オリフィス有効 面積, $\gamma=e_{p} / c_{w} ， R=$ ガ ス定数, 添字 1,2 はそれぞ れ前後のオりフィ スを示す.こてで $P_{1} P_{2}$ は容易に測 定でき, $\gamma_{1} \fallingdotseq \gamma_{2}$ と 考元られ， $A_{1} / A_{2}$ は検定で決められ また第二オリフィ ス前の加䨐器で壁 温とガス温度と等 しく保てるふら $T_{2}$

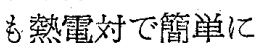
測える。え求 めるガス温度 $T_{1}$ は (2) 式から計算できる.

本測定器はガスタービン研究の際の高速気流温展を 測定するるためN.A.C.A. で研究されたもので，てれを 用いた測定結果は他の方法 (熱電封, ナトリウム $\mathrm{D}$ 線 吸収洗等)とよく一致し，特にふく射その他の誤善無 しに，より高い信賴性をもって高温（4000 Fくらい まで）高速のガス温度を測る事ができる。ただし然焼 ガス中では炭素附差閒題があり，その他誤差の問題 もあるがその解渀方洗も示してある。な打詳細は同著 者による N.A.C.A. T.N. $2167^{-}$参照.

〔小茂鳥和生〕 